\title{
Rogier versus Jottrand: dure beledigingen in de Belgische opiniepers (1861-1863)
}

\section{English summary}

The Belgian Constitution guaranteed political liberty, exemplified by the mandatory competence of the jury for judging political and press offences. However, the constitution did not literally mention quasidelicts. In 1861, liberal statesman Charles Rogier was insulted by the ultramontanist Catholic newspaper Le Journal de Bruxelles. He sued the newspaper's printer under tort law, and obtained a considerable amount of damages, bypassing the jury. Progressive radical lawyer Lucien Jottrand, former member of the Constituent Assembly, argued at length that the constitution exclusively reserved competence for both civil and criminal liability to the jury. The Brussels Court of Appeal and the Court of Cassation rejected this reasoning and insisted on the superior natural law-origins of tort law. Yet, this decision created a risk of private censorship, well documented in the press and in private archives on the legal battle around the Journal de Bruxelles.

\section{Keywords}

Free speech - Belgian constitution - neutrality

Frederik Dhondt ${ }^{1}$

'Une épithète malsonnante, regrettable, et que la droite tout entière a désavouée hier, a été appliquée ces jours derniers par un journal de la capitale à M. Rogier, ministre des affaires étrangères.'

Le Bien Public, 14 december $1861^{2}$

'Le Journal de Bruxelles, feuille pontificale, à bout d'invectives contre l'honorable président du conseil M. Rogier, s'est décidé à l'appeler "petit-fils du bourreau d'Arras». Cette plate grossièreté [...] a provoqué une extrême indignation [...]. La droite est restée catholiquement silencieuse.'

La Presse (Parijs), 14 december $1861^{3}$

'La Belgique serait humiliée, si l'on pouvait dire impunément d'un de ses plus nobles et fidèles serviteurs pendant trente années, d'un homme qui a été un modèle d'honnêteté et de désintéressement, ce qu'en a dit le Journal de Bruxelles.'

Auguste Orts, 7 februari $1862^{4}$

Op tweede Kerstdag 1861 velde de eerste kamer van de rechtbank van Eerste aanleg te Brussel een bijzonder vonnis bij verstek. Josse Delièvre, drukker van de katholieke opiniekrant Le Journal de Bruxelles, werd veroordeeld tot het betalen van een schadevergoeding van tienduizend Belgische frank.

\footnotetext{
${ }^{1}$ Docent, Vrije Universiteit Brussel, Onderzoeksgroep Contextual Research in Law (CORE), suppleantgastprofessor, Universiteit Antwerpen, vrijwillig medewerker, Instituut voor Rechtsgeschiedenis (UGent). De auteur wenst uitdrukkelijk Prof. em. dr. Paul Nève en dr. Regina Nève-Sprenger te danken voor de toegang tot het privé-archief van de familie Nève. De verwijzingen naar inventarisnummers in voetnoten corresponderen met de bescheiden in het archief. Het privé-archief Nève zal eerst nà de volledige inventarisatie naar het Regionaal Historisch Centrum Limburg te Maastricht worden overgebracht. De verwijzingen naar de nummers in de inventaris zijn dus nog niet definitief. Verder gaat onze erkentelijkheid uit naar de anonieme reviewers van dit artikel, alsook naar Els Witte, Jan Velaers, Wouter De Rycke, Yves Deroubaix en Laure Hendrickx voor hun opmerkingen bij een eerdere versie.

${ }^{2}$ Le Bien Public, 14 december 1861. Alle uittreksels uit de Belgische pers zijn het gevolg van een consultatie van de databank www.belgicapress.be, maart-mei 2020.

${ }^{3}$ La Presse, 14 december 1861. Geraadpleegd op www.retronews.fr, 30 april 2020.

234.

${ }^{4}$ Pleidooi gehouden voor de eerste kamer van de rechtbank van eerste aanleg te Brussel, BJ 1862, kol.
} 
Dit aanzienlijke bedrag ${ }^{5}$ moest de schade compenseren die een van 's lands voornaamste staatslieden, minister van Buitenlandse Zaken Charles Rogier (1800-1885), had opgelopen door een belasterende uitlating in de krant. Gezien de prominente positie van alle betrokkenen stond deze rechtszaak in het oog van een publieke storm. ${ }^{6}$

\section{Feiten}

Op maandag 2 december 1861 kondigde een artikel op de eerste pagina van Le Journal de Bruxelles de publicatie aan van een brochure die 'de waarheid aan het licht zou brengen over de mensen en de zaken van het zogenaamde koninkrijk Italië'. Als katholieke krant verdedigde de Journal de Bruxelles de jonge katholieke vrijwilligers die zich in het strijdgewoel hadden gemengd. ${ }^{7}$

In de lente van 1859 was opnieuw een conflict uitgebroken tussen het Oostenrijkse Keizerrijk en het Koninkrijk Piëmont-Sardinië. Met Franse steun werd Oostenrijk gedwongen tot de afstand van Lombardije, in ruil voor de overgang van Nice en Savoye naar Frankrijk. ${ }^{8}$ Opstanden in Parma, Modena, Firenze en een deel van de pauselijke Staten werden gevolgd door plebiscieten en aanhechting bij de groeiende staat in het Noorden. In de lente en zomer van 1860 verjoeg de linkse revolutionair Garibaldi de Bourbon-koning der Beide Siciliën. Op 17 maart 1861 riep het Italiaanse parlement in Turijn Victor Emmanuel II uit tot Koning van Italië.

De juridische transformaties op het Italiaanse schiereiland zijn tot op heden het voorwerp van controverse. De geleidelijke ontmanteling van het systeem van het Congres van Wenen was enkel mogelijk door de bestaande, geldig afgesloten verdragen te schenden. ${ }^{9}$ Het nationaliteitenprincipe dat door juristen Mancini (1817-1888) en Pierantoni (1840-1911) naar voren werd geschoven, was inherent revolutionair: de vereniging van een bevolking kon bestaande verdragen teniet doen en het gebruik van geweld rechtvaardigen. ${ }^{10}$ Dit is precies wat het legitimiteitsprincipe van het Congres van Wenen poogde te verijdelen. De eenmaking van Italië onder een liberaal constitutioneel regime bedreigde meerdere katholieke heersers: de Oostenrijkse keizer, de koning der Beide Siciliën en uiteraard ook de paus.

Beide redenen (gebrek aan respect voor het legitimiteitsprincipe van 1815 en bedreiging van de wereldlijke positie van de paus) brachten ultramontaanse katholieken ertoe om de Belgische regering tot de grootst mogelijke voorzichtigheid aan te manen in haar houding ten aanzien van Piëmont-Sardinië. De doctrinair-liberale meerderheid die het land bestuurde van 1857 tot 1870 stuurde evenwel aan op een snelle erkenning van de nieuwe situatie. België wou de commerciële kansen in een eengemaakt Italië

\footnotetext{
${ }^{5}$ Het gemiddelde dagloon van een volwassen mannelijke textielarbeider in Gent bedroeg in 18612,4 frank. Statistique générale de la Belgique. Brussel, Ministerie van Binnenlandse Zaken, 1865, III, 142.

6 De pleidooien van de verstekzitting verschenen in de zondagseditie van de liberale krant L'Indepéndance Belge, 22 december 1861, p1 en 2.

${ }^{7}$ Over de krant: J. Vander Vorst-Zeegers, Le “Journal de Bruxelles” de 1871 à 1884, Louvain, 1965.

${ }^{8}$ Vredesverdrag tussen Oostenrijk, Frankrijk en Piëmont-Sardinië, Zürich, 10 november 1859, 121 CTS 155.

9 'In patent disregard of international law', S. Marchisio, 'The Unification of Italy and International Law', in: G. Bartolini ed., A History of International Law in Italy. The History and Theory of International Law, Oxford, 2020, 286; M. Šedivý, The decline of the congress system: Metternich, Italy and European diplomacy, Londen, 2018.

${ }^{10}$ E. Mura, 'The Construction of the International Law Discipline in Italy between the Mancinian and Positive Schools', in: Bartolini, A History of International Law in Italy, 109-125.
} 
niet missen. ${ }^{11}$ Bovendien waren de principiële analogieën met de eigen revolutie in 1830 duidelijk. ${ }^{12}$ Waarom zou de wijziging van het internationale status quo in 1830 conform het volkenrecht zijn verlopen, en die in 1859-1861 niet?

In november 1861, onder aanhoudende verhitte debatten tussen de katholieke oppositie en de nieuwe minister van Buitenlandse Zaken Charles Rogier, vond de jonge katholieke markies Alfred de Trazegnies de dood aan de grens tussen de pauselijke Staten en Napels. ${ }^{13}$ De Journal de Bruxelles verkondigde dat enkel een buitenlander' (un étranger) het met 'onverschilligheid' had durven te hebben over dit overlijden. Deze buitenlander was snel gevonden: 'de zoon van een beul uit Arras', waarmee Charles Rogier werd bedoeld. ${ }^{14}$

\section{Het proces in eerste aanleg}

Charles Rogier achtte dit gebruik 'à froid' van zijn naam om publicitaire doeleinden ${ }^{15}$ voldoende om zijn pleitbezorger ${ }^{16}$ Lambert Heernu en advocaten Auguste Orts (1814-1880) ${ }^{17}$ en François Dolez (1806$1883)^{18}$ een burgerlijke vordering te laten instellen tegen Delièvre, drukker van de krant. ${ }^{19}$ De kwaadwilligheid en de gemene intenties van de Journal de Bruxelles hadden schade toegebracht aan een man wiens verdiensten voor het vaderland te meten noch te tellen waren. ${ }^{20}$ De afwezige Delièvre werd ter zitting louter door zijn pleitbezorger Maertens vertegenwoordigd. ${ }^{21}$ De advocaten betoogden dat Delièvres krant Rogier had willen kwetsen door een smadelijke uitlating. De afkomst die de eerbare minister van Buitenlandse Zaken werd aangewreven, zou zelfs de meest geringe burger toelaten om hem

${ }^{11}$ M. Dumoulin, Les relations économiques italo-belges (1861-1914). Mémoires de la Classe des lettres et des sciences morales et politiques, $2^{\mathrm{e}}$ série, dl. 68, Bruxelles, 1990; C. Terlinden, 'La reconnaissance du royaume d'Italie par la Belgique', in: H. Vander Linden en F. L. Ganshof (red.), Mélanges d'histoire offerts à Henri Pirenne par ses anciens élèves et ses amis à l'occasion de sa quarantième année d'enseignement à l'Université de Gand 1886-1926, Bruxelles, 1926, 483-514.

${ }^{12}$ Charles Rogier Hand. Kamer 1861, 28 november 1861, 91: 'Ces pays se sont associés; ils ont nommé leurs représentants, ils ont formé un parlement national. Ils se sont rangés et soumis sous la même loi. Où sont les conquérants, où sont les vaincus, où sont les opprimés, où sont les oppresseurs?' Het integraal verslag van de plenaire vergadering werd geraadpleegd op de website van de Kamer van Volksvertegenwoordigers tussen maart en mei

2020.

https://www.dekamer.be/kvvcr/showpage.cfm?section=/cricra\&language=nl\&cfm=/site/wwwcfm/cricra/cricrage n.cfm?sess=1861620\&type=plen. Over dit debat: F. Dhondt, 'Legal arguments in the debate on recognition of Italian independence in Belgian parliament (November 1861)', Forum Historiae Iuris 2021, ter perse.

${ }^{13}$ S. Sarlin, Le légitimisme en armes : histoire d'une mobilisation contre l'unité italienne. Bibliothèque des Ecoles françaises d'Athènes et de Rome, dl. 355, Rome, 2013, 203-204. Orts stelt dat de Trazegnies in dienst stond van Frans II van Bourbon, de laatste koning van Napels. BJ 1862, kol. 233.

${ }^{14}$ Journal de Bruxelles, 2 december 1861. De brochure werd verder aangeprezen omdat ze het 'pijnlijk emotionele' verhaal van de moord op Pimodan bevatte, alsook het verhaal van een voormalig geheim agent in dienst van Cavour. De uitdrukking 'Rogier, d'Arras' werd ook gebruikt door de ultramontaanse krant Le Bien Public (15 december 1861).

${ }^{15}$ De uitdrukking wordt gebruikt door Orts, BJ 1862, kol. 233.

${ }^{16}$ Over deze bijzondere instelling, opvolger van de procureur uit het Ancien Régime, die in België pas met het Gerechtelijk Wetboek van 1967 werd afgeschaft, verwijs ik naar het recente doctoraat van $M$. Vankeersbilck. Maarten Vankeersbilck, Justitie in de steigers: gerechtelijke hervormingen in België: de moeizame weg naar het gerechtelijk wetboek, Gent, UGent, onuitg. doctoraatsverhandeling, 2019, 387-395.

${ }^{17}$ C. Mesdach te ter Kiele, 'ORTS (Auguste)', Biographie Nationale dl. XVI, 1901, kol. 336-342.

${ }^{18}$ R. Wellens, 'DOLEZ (François-Jean-Baptiste-Adélaïde-Auguste), Biographie nationale (suppl.), dl. VII, 1969, kol. 189-190.

${ }^{19}$ Voor de pleidooien van Dolez en Orts: BJ 1862, kol. 241-245.

${ }^{20}$ Indépendance Belge, 22 december 1861, 2.

${ }^{21}$ Afschrift beslissing Rb. Brussel, geleverd door de studie van meester Léon Max, s.d., Beek-Ubbergen, Archieven Nève (AN), inv. nr. 115, f. ${ }^{\circ}$ 1, 4. Meer dan een uitstel van de zitting, gepland voor 14 december, naar 26 december, verkreeg Maertens evenwel niet. Meester Léon Max, die deze afschriften aanlevert, vertegenwoordigt Charles Rogier in beroep. Zie afschrift arrest Brussel, 2 juni 1862, Ibid., f. $45 \mathrm{r}^{\circ}$. 
te minachten. ${ }^{22}$ De begroting van de schade kon niet anders dan tot een aanzienlijk bedrag leiden, gelet op het 'voorname karakter van de krant die zich deze uitlating veroorlooft', enerzijds, en de 'maatschappelijke positie van de eiser', anderzijds.

De eiser voerde aan dat de bezwarende zin in de Journal de Bruxelles zonder enige twijfel op hem alludeerde, door te verwijzen naar zijn woorden in de Kamer. Rogier had zich een paar dagen eerder al ironisch uitgelaten over de 'ingebeelde gevaren die voortvloeien uit de erkenning van het Koninkrijk Italië' en laconiek verklaard dat het 'Europees publiekrecht' zich zonder problemen aanpaste aan interne revoluties. Derden konden niet anders dan een feitelijke toestand erkennen, en er zich bij neerleggen. Of was de katholieke oppositie vergeten dat uitgerekend de Heilige Stoel, die zich nu op het legitimiteitsprincipe beriep, zich verzet had tegen de Weense Slotakte? ${ }^{23}$

Verder onderstreepte Rogier dat Belgische onderdanen die zich mengden in buitenlandse conflicten zich dienden te houden aan een 'effacement moral' (moreel rimpelloze houding), om de eeuwige neutraliteit van het land niet in gevaar te brengen. ${ }^{24}$ De permanente neutraliteit was voor Rogier de 'Europese bestaansvoorwaarde van het land. ${ }^{25}$ Helpen of bijstand bieden ten voordele van een belligerent, en dus partij kiezen voor een van de soevereinen in een gewapend conflict, was niet alleen voor de staatsorganen, maar ook voor onderdanen uit den boze. Ter zitting citeerde de minister twee 'van de meest hooggeachte auteurs' uit de doctrine. ${ }^{26}$ Rogier zette zijn tussenkomst verder door te verwijzen naar artikel 21 van het Burgerlijk Wetboek, dat de 'publieke ongehoorzaamheid' bestrafte met het verlies van de Belgische nationaliteit. ${ }^{27}$ Aan het 'mooie recht van de onafhankelijkheid' waren verplichtingen verbonden, met name ook degene om niet te tolereren dat een ander wordt aangedaan wat men zelf wil vermijden. ${ }^{28}$ Rogier verwierp hiermee de katholieke argumenten over het karakter van de louter voor de Staat, en niet voor zijn burgers geldende neutraliteitsverplichting. ${ }^{29}$ Liberaal kamerlid Jean-Baptiste Nothomb (1805-1881) ${ }^{30}$ verdedigde de katholieke vrijwilligers door te wijzen op de 'natuurlijke vrijheid', die elk individu in zich droeg.

\footnotetext{
22 Volgens het katholieke Handelsblad van Antwerpen: 'we moeten niet bekennen, dat we liever niet dan wel op zoo'n [sic] manier ons doopceel zouden zien ligten'. Handelsblad van Antwerpen, 13 december 1861.

${ }^{23}$ Hand. Kamer, 21 november 1861, 28.

24 Ibid., 31.

25 Over het neutraliteitsconcept in de negentiende eeuw: F. Dhondt, 'Neutralité permanente, interprétations mutantes: la neutralité belge à travers trois traités de juristes', Tijdschrift voor Rechtsgeschiedenis [hierna : TRG], 2018, afl. 3-4, 188-214.

${ }^{26}$ Rogier citeerde de Deen Martin Hübner, auteur van een bekend traktaat over de rechten van neutralen: 'La neutralité consiste dans une inaction entière relativement à la guerre, et dans une impartialité exacte et parfaite, manifestée dans les faits à l'égard des belligérants'. M. Hübner, De la saisie des bâtiments neutres, ou du droit qu'ont les nations belligérantes d'arrêter les navires des peuples amis, Den Haag, 1759, 130. De tweede geciteerde auteur was Galiani, 'Chiamo neutralità lo stato di quel Principe, il quale ritrovando in stato di quiete, d'amicizia, o di alleanza con altri Principi, che erano in pace tra loro, continua a rimanere nello stesso stato erso di essi, ancorchè sia nata o rottura, o fuoco di guerra tra quelli.' F. Galiani, De' doveri de ' principi neutrali verso i principi guerreggianti, e di questi verso i neutrali, libri due, Milaan, 1782, 7 ; Charles Rogier, Hand. Kamer, 21 november 1861,31 .

${ }^{27}$ Hand. Kamer, 21 november 1861, 31.

28 Ibid., 32.

${ }^{29}$ Rogier (geciteerd door Orts): als staatsman in 'un pays qui a comme premier devoir en Europe la neutralité envers tous les pays' is het niet mogelijk om zich te houden aan het eventuele private begrip dat men kan opbrengen voor wie bereid is te sterven voor zijn idealen. BJ 1862, kol. 232-233. De toepassing van de Belgische permanente neutraliteit op individuen kwam het sterkste tot uiting bij de Belgische wapenleveringen tijdens de Krimoorlog, een decennium eerder. Zie F. Dhondt, 'Permanent neutrality or permanent insecurity? Obligation and self-interest in the defense of Belgian neutrality', in: I. Van Hulle en R. Lesaffer (red.), International Law in the Long 19th Century (1776-1914). From the Public Law of Europe to Global International Law? Legal History Library, 28; Studies in the History of International Law, 11, Leiden/Boston, 2019, $159-185$.

${ }^{30}$ Zie C. Chevalier, 'La mission de Jean-Baptiste Nothomb à Paris d'août 1856. Jeux de pouvoir et diplomatie officielle au sein du Gouvernement belge', Revue d'histoire diplomatique, 2015, 5-20.
} 
Op 28 november, een week later, verklaarde Rogier dat hij niet in staat was om de jonge Belg in kwestie 'moreel te veroordelen', maar dat het toch wel duidelijk had moeten zijn aan welk gevaar men zich blootstelt door zich te mengen in een buitenlands conflict. De Trazegnies wist waar hij zou vechten. De wetten van de oorlog zijn 'barbaars en wreed' ${ }^{31}$ De Belgische regering heeft zich niet beziggehouden met beschermingsmaatregelen voor Belgen in dergelijke situaties, en zou dat ook niet doen. In de eerste decennia van het nationale bestaan was dit evenmin gebeurd in de Spaanse carlistische burgeroorlog. Toen de Belgische regering koningin Isabella reeds erkend had, waren er nog Belgen vertrokken om te vechten. Ook al worden burgers omgebracht in strijd met het oorlogsrecht, de regering kon niet tussenkomen om hen te beschermen. ${ }^{32}$

De 'leugenachtige en schandelijke' aantijging van de Journal de Bruxelles zou evenwel niet voldoen aan de criteria geëist in het Strafwetboek. ${ }^{33}$ Bijgevolg kon ze volgens de raadslieden van de minister niet worden voorgelegd aan de repressieve (strafrechtelijke) juryrechtspraak. Dat belet evenwel niet dat ze te zeer de goede naam en faam van de eiser en diens familie aantast. Er was volgens de eiser een krachtiger antwoord nodig dan het loutere misprijzen dat de uitlating vanzelf opwekte.

Delièvre werd, als drukker van de Journal de Bruxelles, acht dagen na publicatie van het artikel op korte termijn gedagvaard om voor de rechter te verschijnen. De krant publiceerde op 17 december 1861 een princiepsstandpunt. De pers kon 'moreel noch juridisch' verantwoordelijk worden gehouden voor de Kamers die 'onder druk van de meute verkozen waren', noch voor de rechtbanken 'bemand door het ministerie van de tirannie'. ${ }^{34}$ Dit is een duidelijke verwijzing naar de bezetting van de zetels van de Brusselse rechtbanken. Een hedendaags observator neemt bijvoorbeeld met verbazing kennis van het feit dat eerste voorzitter van het hof van beroep Ferdinand De Page (1794-1874), die de zaak later zal behandelen, meer dan twintig jaar lang gemeenteraadslid was in Brussel-Stad, voor dezelfde politieke partij als de geïntimeerde, samenvallend met een lange carrière als raadsheer (1830-1867) ${ }^{35}$

Uiteraard stelde de krant enkel verantwoording schuldig te zijn aan de publieke opinie, 'représentée au besoin par le jury'. ${ }^{36}$ Het had niet minder dan een volle week geduurd voor iemand aanstoot had genomen aan de publicatie van 2 december. De krant betoogde dat de minister van Buitenlandse Zaken lichtgeraakt was, en normaal gezien niet kon worden gelinkt aan de uitdrukking 'zoon van de beul uit Arras'. Parlementsleden die in de openbaarheid de krant kapittelden, gaven in privéconversaties toe dat ze het stuk niet eens gelezen hadden. Wie zou beter de macabere dreigementen van Rogier ten uitvoer kunnen leggen dan Orts, die eerder zelf van een vergelijkbare sarcastische onverschilligheid blijk had gegeven? De regering-Frère dacht wellicht dat alles toegelaten was. Ze blaft openlijk naar de 'factieuze' pers, maar heeft zelf niet meer dan 'un coeur de biche'. ${ }^{37}$

De liberale La Meuse trok partij voor Rogier, en had het over 'epileptische' artikels van de voorname katholieke krant, die redeloos van leer trok tegen liberale politici. ${ }^{38} L$ 'Echo $d u$ Parlement ging

${ }^{31}$ Hand. Kamer, 28 november 1861, 86; BJ 1862, kol. 212-213.

${ }^{32}$ Hand. Kamer, 28 november 1861, 91.

${ }^{33}$ Art. 367 lid 1 Strafwetboek 1810: 'Sera coupable du délit de calomnie celui qui, soit dans des lieux ou réunions publics, soit dans un acte authentique et public, soit dans un écrit imprimé ou non qui aura été affiché, vendu ou distribué, aura imputé à un individu quelconque des faits qui, s'ils existaient, exposeraient celui contre lequel ils sont articulés à des poursuites criminelles ou correctionnelles, ou même l'exposeraient seulement au mépris ou à l a haine des citoyens'.

${ }^{34}$ Journal de Bruxelles 17 december 1861.

${ }^{35}$ In tegenstelling tot het cumulverbod tussen een mandaat als parlementair en een functie als magistraat, was deze lokale cumul niet uitgesloten. L. Tierenteyn, 'PAGE (Ferdinand-Joseph-Ghislain Baron De)', in: Biographie nationale de Belgique XVI (Bruxelles 1901) 470-471. Ferdinand De Page werd in februari 1863, ten tijde van het proces-Rogier, herbenoemd in de raad van toezicht van het Koninklijk Atheneum te Brussel, als lid van de gemeenteraad. Indépendance Belge, 16 februari 1863.

${ }^{36}$ Journal de Bruxelles, 17 december 1861.

${ }^{37}$ Ibid.

${ }^{38}$ La Meuse, 18 december 1861. 
verder, door te stellen dat de Journal de Bruxelles de grenzen van de normale journalistieke zorgvuldigheid had overschreden. Of begreep de krant haar eigen 'intérêts et obligations morales' niet? ${ }^{39}$ Het ware beter om zich ver te houden van een hangende rechtszaak, eerder dan zich te laten provoceren door minister van Financiën Walthère Frère-Orban, die de Kamer had opgeroepen om een resolutie aan te nemen tegen de krant. ${ }^{40}$ Door de belediging van Rogier te ontkennen, was de deur geopend voor een polemische 'race to the bottom'. Wie was gebaat bij het denigreren van politici die eenvoudig een andere opinie hadden? 'L'intérêt conservateur, l'intérêt social' vereisten dat men de mensen respecteerde. Het gedrag van de krant kon toch bezwaarlijk conform 'cette religion qui prescrit l'amour du prochain pour l'amour de Dieu' zijn. Onpartijdigheid, loyauteit en de grootst mogelijke reserve tegenover de onafhankelijkheid van de magistratuur, en niets anders, hoorde de houding van een redactie te dicteren.

De rechtbank zag geen obstakel in de dagvaarding, gelet op het feit dat 'noch uitgever noch auteur van het stuk' waren tussengekomen om Delièvre te behoeden voor ansprakelijkheid. ${ }^{41}$ Dit laat de ruimte aan Delièvre om eventueel via een regresvordering een deel van de schadevergoeding te recupereren ten aanzien van drukker en uitgever. Men zou nochtans kunnen opmerken dat het een feit van algemene bekendheid vormde dat Paul Nicolas Joseph Nève (1822-1901), ridder in de orde van Frans II van Bourbon, de laatste koning der Beide Siciliën, ${ }^{42}$ als uitgever de Journal de Bruxelles had overgenomen. Nève, die pas in de zomer van 1862 tussenkomt in een latere procedure om de tenuitvoerlegging van de uitspraak te betwisten, zal dit zelf aanvoeren voor de rechtbank van eerste aanleg. Het is een mysterie waarom de vordering van Rogier niet tegen hem gericht was. Nève heeft bovendien later toegegeven de auteur te zijn geweest van de vermelding op de eerste pagina van de krant op 2 december 1861. Het lijkt weinig waarschijnlijk dat de raadslieden van Charles Rogier dit niet hadden kunnen aantonen, zeker nu het een man betreft, die omschreven werd als 'tout l'opposé d'un homme rassis: c'était un volcan, qui faisait éruption plusieurs fois par jour. ${ }^{43}$

De rechtbank was van oordeel dat de uitlating in de krant een echte 'diffamation' (eerroof) uitmaakte. De krant had de eiser geassocieerd met een afkomst die 'pour le plus simple citoyen' (voor zelfs de meest nederige burger) een reden zou vormen om Charles Rogier te minachten, naar de huidige stand van de zeden ('par l'état de nos moeurs'). ${ }^{44}$ Zelfs de meest blinde politieke passie kon een dergelijke misstap niet rechtvaardigen. De uitschuiver was in dit geval des te erger, omdat men het foutieve karakter van de uitlatingen eenvoudig kon nagaan. Bovendien lieten de hoge maatschappelijke

${ }^{39}$ L'Echo du Parlement, 18 december 1861.

${ }^{40}$ Voor Le Journal de Bruxelles niet meer dan een 'comédie parlementaire'. 13 december 1861.

${ }^{41}$ Beslissing bij verstek 26 december 1861, o.c., $\mathrm{f}^{\circ} 3$. Dit is compatibel met de weigering van de plenaire vergadering van het Nationaal Congres om de vermelding 'behalve in geval van medeplichtigheid' weg te laten in de zinsnede die binnen artikel 18 lid 2 oud Gw. de (strafrechtelijke) aansprakelijkheid van auteur, drukker, uitgever en verspreider te regelen. 'La censure des imprimeurs, cent fois plus nuisible à la liberté que celle du pouvoir' (tussenkomst van Charles de Brouckère (1796-1860) in het Nationaal Congres, geciteerd bij J. Velaers, De Grondwet: een artikelsgewijze commentaar, Brugge, 2019, dl. I, 547). Drukker, uitgever en verspreider mogen niet ontmoedigd worden om hun essentiële functie voor de publieke opinie waar te nemen. Deze beperking van aansprakelijkheid wordt ook op burgerrechtelijk vlak aangehouden. Ibid., dl. I, 557 ; J. J. Thonissen, Constitution belge annotée, offrant, sous chaque article, l'état de la doctrine, de la jurisprudence et de la législation, Hasselt, 1844, 80-81; B. Delbecke, De lange schaduw van de grondwetgever : perswetgeving en persmisdrijven in België (1831-1914), Gent, 2012, 434.

${ }^{42}$ L. Nève, Notices généalogiques sur la famille Nève originaire de Tournai, Gent, z.n., 1910. 41.

43 'Histoire d'un journal', gepubliceerd door Le Petit Belge (1899), AN, inv. nr. 421 (krantenknipsels).

${ }^{44}$ Beslissing bij verstek 26 december 1861, o.c., $\mathrm{f}^{\circ} 4$. Orts voegde tijdens zijn pleidooi verontwaardigd toe dat de schandvlek op de reputatie van de minister zou afstralen op zijn gezin en andere verwanten, met niet in de laatste plaats 'des femmes, des jeunes filles, pour lesquelles votre imputation, si elle n'était pas une injure, pouvait être une atteinte à la carrière qui leur était réservée', BJ 1862, kol. 233. 
positie van de eiser en de voornaamheid van de krant geen twijfel. ${ }^{45}$ De uitlating over Rogier werd zelfs niet weerlegd in de komende edities van de krant. Bijgevolg meende de rechtbank het gevraagde bedrag integraal te kunnen toekennen.

De eerste kamer, voorgezeten door ondervoorzitter van de rechtbank Jules Vauthier (18111874) ${ }^{46}$ oordeelde in een korte beslissing en na advies van substituut-procureur des Konings Edouard de le Court (1827-1907), dat Delièvre tienduizend Belgische frank schadevergoeding verschuldigd was, en beval de aanplakking van tweehonderd kopieën van de uitspraak, alsook een verspreiding in tien kranten 'in Brussel en de provincie'. De uitspraak werd uitvoerbaar verklaard bij voorraad, en betekend aan pleitbezorger Maertens bij gerechtsdeurwaardersexploot.

Onmiddellijk in het nieuwe jaar, op 3 januari, betekende Delièvre een verzoekschrift aan de pleitbezorger van de minister van Buitenlandse Zaken om zijn verzet kenbaar te maken tegen de uitvoering bij voorraad. Het verzet werd onder andere gegrond op artikel 98 van de Belgische Grondwet van 1831 , dat de jury instelde voor criminele zaken, politieke- en persmisdrijven. ${ }^{47}$ Advocaat Jottrand (1804-1877 $)^{48}$ stelde dat de tekst van de Grondwet geen onderscheid maakte tussen de burgerlijke vordering en de strafvordering. In het voorliggende geval, waarin een enorme schadevergoeding werd geëist, achtte hij dit ook logisch.

Het vaststellen van burgerlijke 'schuld' (culpabilité) en strafrechtelijke aansprakelijkheid konden niet van elkaar gescheiden worden voor politieke misdrijven, aldus de eisende partij. Waarom zou het anders geweest zijn voor persmisdrijven? ${ }^{49}$ Het had evident moeten zijn voor de rechtbank dat de advocaten van Rogier probeerden om de kwalificatie van de feiten als misdrijf terzijde te schuiven, en zo de grondwettelijke garantie van de jury uit te wissen. Indien de krant kwaadwilligheid ('méchanceté') werd verweten, dan kon het toch niet anders of er was sprake van een misdrijf in de zin van artikel 375 van het Strafwetboek $?^{50}$ De rechtbank van eerste aanleg had zich eerder onbevoegd moeten verklaren om kennis te nemen van de vordering. ${ }^{51}$

45 'Un de nos grands journaux politiques', en niet zomaar ' $u n$ de ces petits journaux [...] qu'on appelle généralement journaux de bas étage', aldus substituut-Procureur des Konings De le Court (Indépendance Belge, 22 december 1861).

${ }^{46}$ Alle gegevens over magistraten in dit stuk werden ontleend aan de magistratendatabank van het project Digithémis (IUAP Justice and Society), www.digithemis.be.

${ }^{47}$ Beslissing op verzet 23 januari 1862, o.c. $_{\text {, f. }}{ }^{\circ}$ 7. Jottrand voerde uiteraard aan voor zijn cliënt dat in een dergelijk geval de burgerlijke vordering -indien zij niet tegelijk werd uitgeoefend met de strafvordering- voorrang moest geven aan de publieke, uitgeoefend door het Openbaar Ministerie. Artikel 2, Voorafgaande Titel Code d'Instruction Criminelle.

${ }^{48}$ Lucien Léopold Jottrand, lid van het Nationaal Congres, verkozen te Brussel. Over Jottrand: E. Witte, Belgische Republikeinen. Radicalen tussen twee Revoluties (1830-1848), Antwerpen, 2020, 61-64. Jottrand liet zich opmerken tijdens het debat over de jury- en persdecreten in de zomer van 1831: Delbecke, De lange schaduw, 83.

49 'une infraction de droit commun à laquelle la presse a servi d'instrument'. Jean Joseph Thonissen, La Constitution belge annotée (3de druk; Bruxelles 1879) 300.

${ }^{50}$ Art. 375 Code Pénal 1810: 'Quant aux injures ou aux expressions outrageantes qui ne renfermeraient l'imputation d'aucun fait précis, mais celle d'un vice déterminé, si elles ont été proférées dans des lieux ou réunions publiques, ou insérées dans des écrits imprimés ou non, qui auraient été répandus et distribués, la peine sera une amende de $16 \mathrm{fr}$. à $500 \mathrm{fr}$.'.

${ }^{51}$ Beslissing op verzet 23 januari 1862, o.c., f ${ }^{\circ}$ 8. In ondergeschikte orde (Ibid., f. $\left.9 \mathrm{r}^{\circ}\right)$ argumenteerde Jottrand dat de schade onvoldoende precies was begroot, in weerwil van artikel 15 en 16 van de wet van 25 maart 1841 over de bevoegdheid in burgerlijke zaken (Pasin. 1841, 67-105) die voorschreef dat de waarde van roerende goederen door de eiser diende te worden bepaald, geschat en bijzonder gemotiveerd om een schadevergoeding te kunnen eisen. In dit geval diende de eis onontvankelijk te worden bevonden, en moet de zaak van worden geschrapt. Rogier toonde volgens Jottrand noch aan hoe, noch waarom hij schade had geleden (BJ 1862, kol. 221). Over deze wet, zie Vankeersbilck, Justitie in de steigers, 98-99. Dit argument werd afgewezen bij de behandeling ten gronde van de zaak op 15 februari 1862. Rb. Brussel, 15 februari 1862, o.c., f ${ }^{\circ}$ 19-26; BJ 1862, kol. 209-246. 
De zaak werd op grond van het aangetekende verzet opnieuw behandeld door dezelfde kamer op 23 januari 1862..$^{2}$ De debatten werden gepubliceerd in de Belgique Judiciaire. Ook de liberale kranten La Meuse ${ }^{53}$ en L'Indépendance Belge $e^{54}$ brachten uitgebreid verslag uit. Delièvre werd ditmaal wel bijgestaan door een raadsman: de bekende advocaat en publicist Lucien Jottrand. Dit voormalig lid van het Nationaal Congres, door zijn biograaf Julien Kuypers omschreven als 'franc-tireur dévoué à la chose publique' zou de zaak van de krant uitgebreid bepleiten. ${ }^{55}$ Jottrand had eerder de orangistische krant Le Messager de Gand,${ }^{56}$ de satirische krant Les Euménides, de radicalen Kats en Spilthoorn en de communistische arbeider Nicolas Coulon verdedigd voor assisenhoven. ${ }^{57}$

De eerste kamer van de rechtbank van eerste aanleg te Brussel had evenwel niet veel oren naar de eerste tussenkomst van meester Jottrand. In een korte overweging werd komaf gemaakt met zijn hoofdargument, dat inging tegen 'een onbetwiste rechtspraak en doctrine in België'. De exceptie van onbevoegdheid werd afgewezen als 'mal fondée'. Er was geenszins sprake van een misdaad of wanbedrijf, hoe 'schadelijk en kwaadwillig' de uitlating van de Journal de Bruxelles ook was geweest. ${ }^{58}$ Niet alle schadeverwekkende fouten kunnen immers als misdrijven worden gekwalificeerd: quasidelicten zijn talrijker dan delicten. Net daarom had de wetgever in artikel $1382 \mathrm{BW}$ de mogelijkheid voorzien om een burgerlijke vordering in te stellen. Wanneer de vordering voor de 'repressieve tribunalen' gebracht wordt, belast met de openbare vordering, is dit een uitzonderlijke situatie. ${ }^{59}$

De rechtbank vervolgde haar afwijzing van het argument door te stellen dat de hoven van assisen louter over de strafrechtelijke repressie oordeelden, vanuit het algemeen belang. Dit belette evenwel niet dat ook in geval van vrijspraak van de beschuldigde, een schadevergoeding kon worden toegekend aan de burgerlijke partij. ${ }^{60}$ Schadevergoeding was dus mogelijk, los van de procedurele bescherming tegen de overheid. De vraag van de eiser op verzet zou de burgerlijke vordering volledig ondergeschikt hebben gemaakt aan de publieke, waardoor het slachtoffer van een burgerlijke fout niet in staat zou zijn geweest herstel te bekomen indien het openbaar ministerie niet optrad. Bovendien doofde de strafvordering uit bij overlijden van de beschuldigde, maar kon een burgerlijke veroordeling nog verhaald worden op de nalatenschap. ${ }^{61}$ De aangehaalde feiten konden niet worden geklasseerd als een belediging, noch als laster. $^{62}$

Bij een volgende zitting op 15 februari 1862 behandelde de rechtbank de grond van de zaak. Jottrand erkende ter zitting dat de uitspraak over Rogiers afkomst 'elke grond miste' ${ }^{63}$, maar voerde aan

${ }^{52}$ Beslissing op verzet 23 januari 1862, o.c. $^{\circ}$ f. 6 .

${ }^{53}$ La Meuse, 5 februari 1862, 3.

${ }^{54}$ Indépendance Belge, 5 februari 1862, 3; 12 februari 1862, 3.

55 Julien Kuypers, 'JOTTRAND (Lucien)', in: Biographie Nationale de Belgique, dl. XXX (Suppl., II) Brussel, 1958, 487.

${ }^{56}$ Orts herinnert Jottrand aan deze zaak op de zitting van 1 februari 1862, La Meuse, 5 februari 1862.

${ }^{57}$ Delbecke, De lange schaduw, 131, 139, 147, 191, 227-228.

${ }^{58}$ Beslissing op verzet 23 januari 1862, o.c., $\mathrm{f}^{\circ} 11$.

${ }^{59}$ Beslissing op verzet 23 januari 1862 , o.c., $\mathrm{f}^{\circ} 12$.

${ }^{60}$ Ibid., $\mathrm{f}^{\circ} 13$.

${ }^{61}$ Ibid., $\mathrm{f}^{\circ} 13$.

${ }^{62}$ Het verzet van Delièvre werd eveneens afgewezen. Hij had niet gereageerd bij het eerst toegekende uitstel op een eerste zitting op 21 december 1861, en was niet in staat om het bewijs te leveren van een aannemelijke onwetendheid ten aanzien van een vormelijk correcte dagvaarding.

${ }^{63} \mathrm{Rb}$. Brussel, 15 februari 1862, o.c., f ${ }^{\circ} 27$. Jottrand verwoordt het als volgt: 'M. Rogier $n$ 'est pas le fils du bourreau d'Arras; à dire ce que son père a été; à prouver que nous n'avons pas été guidé par une intention méchante, ni par le désir de nuire personnellement à M. Charles Rogier.' Ter zitting op 18 januari 1862 voerde Jottrand aan dat een genealogisch onderzoek had uitgewezen dat de overgrootvader van Rogier in het graafschap Henegouwen woonde, gehuwd was met een dame met een 'Belgische familienaam', en de familie sedert generaties het eerbare beroep van handelaar uitoefende ('honnête marchand du caractère le plus débonnaire'). Het gerucht over Rogier's afstamming was begin 1861 nieuw leven ingeblazen door de publicatie van het pamflet Le petit-fils du bourreau de Cambrai (Jean-Paul Faber, Scènes de la vie privée des Belges,Paris, Dentu, 1861). L. Jottrand, 
dat de kranten Les Euménides (Brussel) en Messager de Gand in 1838 reeds dergelijke uitspraken van de advocaat Michaëls over Rogier hadden weergegeven. ${ }^{64}$ Jottrand voerde verder nog aan dat het schadeverwekkend feit 'zo weinig ernstig' was, dat er maar een strafrechtelijke boete van ten hoogste 5 frank voor zou kunnen worden geëist. ${ }^{65}$ Bovendien beging de Journal de Bruxelles deze misstap duidelijk te goeder trouw, aangezien Rogier destijds niet eens had gereageerd.

De rechtbank aanvaardde dit argument niet, aangezien de redactie ruimschoots de mogelijkheid had gehad om de valsheid van de informatie na te gaan. De Messager de Gand, door de advocaten van Rogier beschreven als een 'feuille de bas étage ${ }^{96}$, had vierentwintig jaar eerder 'met een volgehouden hardnekkigheid', allen die hadden 'bijgedragen tot de vestiging van de Belgische nationaliteit' gekweld en getergd. ${ }^{67}$ Toch had dit niet volstaan om te stellen dat Rogier geen reden meer had om op te treden. Een voorname krant als de Journal de Bruxelles had zich -in de woorden van substituut-procureur des Konings de le Court, schuldig gemaakt aan een 'imprudence excessivement grave' ${ }^{68}$

Er was duidelijk iets blijven hangen van de smaad uit 1838, waardoor het noodzakelijk was om met een geding te verhinderen dat de roddels zouden verstenen tot een 'fait avéré'. De advocaten van Rogier hadden aangevoerd dat de publicatie door de Journal de Bruxelles de aanleiding was geweest voor het herhalen van de belediging 'beulenzoon' in de lokale pers in Mechelen en Luik. ${ }^{69}$ Dat de uitlatingen gebeuren in een verhit politiek debat, vermag niet uit te wissen dat de gezins- en persoonlijke eerbaarheid van Rogier aangevallen zijn geweest. Alle door Jottrand aangehaalde omstandigheden zouden bij de begroting van de schadevergoeding ook geen rol mogen spelen: de advocaat van de eiser in de verzetsprocedure vergeet dat 'des motifs d'excuse et d'atténuation' enkel voor de strafgerechten betekenis hebben. De 'ernstige' aantasting die Rogier had ondergaan, veroorzaakte een schade die niet meer ongedaan gemaakt kon worden, zelfs niet na intrekking van de woorden door de krant zelf. ${ }^{70}$

\section{Hoger beroep}

'Supposons un membre du Congrès qui, après avoir voté la Constitution, se serait enfermé dans une retraite absolue où il se serait isolé des bruits du monde [...] Qu'est donc devenu l'art. 98 de la Constitution? A-t-il été abrogé ou révisé?'

Henri Schuermans, Belgique Judiciaire, 7 april $1861^{71}$

Mémoire présenté à la première chambre de la Cour d'appel de Bruxelles, Brussel, s.n., 1862, 5 ; BJ 1862 , kol. 215-218, 224-231. Over deze kwestie : E. Discailles, Charles Rogier (1800-1885) d'après des documents inédits, Bruxelles, 1892, I, 13-23.

64 'Wat de Journal de Bruxelles zegde, zong men reeds in onze straten van over 25 jaren' (Handelsblad van Antwerpen, 13 december 1861). De toeschrijving door Michaëls kaderde in een ruzie rond een lege zitplaats in de Antwerpse Opera, toen Rogier het ambt van provinciegouverneur uitoefende (1834-1840). Jottrand vond het merkwaardig dat Rogier niets ondernam tegen de orangistische krant Le Messager de Gand, die de 'grands négociants' uit Antwerpen en Gent en belangrijke edelen als leespubliek had. BJ 1862, kol. 218-220.

${ }^{65}$ Jottrand, Mémoire, 7; BJ 1862, kol. 214-215. Hierbij wordt verwezen naar artikel 376 Code Pénal 1810: 'Toutes autres injures ou expressions outrageantes qui n'auront pas eu ce double caractère de gravité et de publicité ne donneront lieu qu'à des peines de simple police.'

${ }^{66}$ BJ 1862, kol. 231.

${ }^{67} \mathrm{Rb}$. Brussel, 15 februari 1862, o.c., $\mathrm{f}^{\circ} 27$.

${ }^{68}$ Indépendance Belge, 12 februari 1862, 3.

${ }^{69}$ BJ 1862, kol. 223-224.

${ }^{70} \mathrm{Rb}$. Brussel, 15 februari 1862, o.c., f ${ }^{\circ} 29$.

${ }^{71}$ H. Schuermans, 'Liberté de la presse - de la compétence des tribunaux civils en matière de presse', $B J$ 1861, kol. 433-440. Henri Schuermans (1825-1905) was Procureur des Konings te Hasselt ten tijde van deze bijdrage, of, zoals hij het zelf verwoordt: 'simple soldat dans la phalange des officiers du ministère public qui compte tant d'hommes éminents en France et en Belgique'. Uiteraard is deze bescheidenheid retorisch instrumenteel: de geciteerde Franse autoriteiten Joseph Borelly (1788-1878, procureur-generaal bij het hof van beroep te Aix-en-Provence) en de grote 'Dupin aîné' (1783-1865, procureur-generaal bij het Hof van Cassatie), 


\section{Ten gronde : artikelen 14, 18 en 98 van de Grondwet}

Jottrand zette de woordenstrijd voort in hoger beroep. Het arrest van 2 juni $1862^{72}$ is veel uitgebreider dan de beslissingen van de rechtbank van eerste aanleg. Jottrand publiceerde zijn conclusie en een synthetische weergave van de debatten in een tot nu toe onbesproken brochure van 49 pagina' $\mathrm{s}^{73}$. Hij probeerde (uiteraard) de feiten te verzachten. Hoe kan men beter het publiek verleiden, dan door te verwijzen naar een vers parlementair debat? ${ }^{74}$ Wie kan overigens een katholiek auteur als Nève, gepassioneerd door het glorieuze 'Brabantse' verleden, aanwrijven dat hij zich geraakt voelt door het trieste lot van een telg uit het geslacht de Trazegnies? ${ }^{75}$ Rogier, die behoort tot 'ceux qui ont reçu l'éducation toute française', had met andere woorden meer begrip moeten opbrengen voor wie wél nog aan de traditionele nationale voorgeschiedenis hechtte.

Jottrand breidde de oorspronkelijke middelen in verzet uit tot een uitgebreidere argumentatie, waarin de fundamentele rechten en vrijheden uit de Belgische Grondwet centraal stonden. Artikel 98 werd gekoppeld aan artikel 14 (de vrijheid van meningsuiting) en 18 (de persvrijheid). ${ }^{76}$ Jottrand stelde dat de redactie van beide artikelen ruimte voor interpretatie liet. De opeenvolgende bespreking van verschillende thema's rond de kerstdagen van 1830 maakte volgens Jottrand duidelijk dat de intentie van het Nationaal Congres dezelfde was in beide gevaleln. Artikel 14 heeft het over de 'vrijheid om zijn [of haar] mening op elk gebied te uiten [...] behoudens de vervolging van de misdrijven begaan ter gelegenheid van het gebruik maken van die vrijheden'. Artikel 18 stelt dan weer dat de 'drukpers vrij is' en de censuur nooit kan worden ingesteld. Uitgever, drukker of verspreider kunnen niet worden 'vervolgd' indien de schrijver bekend is en zijn woonplaats in België heeft. ${ }^{77}$

Jottrand vestigt van het begin de aandacht op de begrippen 'misdrijven' en 'vervolging'. ${ }^{78}$ Volgens hem blijkt hieruit dat bij het opstellen van de Grondwet, waarbij hij zelf actief betrokken was als lid van het Nationaal Congres, enkel de strafrechtelijke repressie bedoeld was. Burgerlijk herstel zou slechts geoorloofd zijn indien de strafrechtelijke aansprakelijkheid werd vastgesteld. Dit brengt Jottrand in verband met artikel 98, dat het heeft over 'politieke misdrijven en persmisdrijven'. De Grondwet zou dus de pers enkel strafrechtelijk verantwoordelijk hebben willen houden, en dit bij uitsluiting van andere jurisdicties aan de juryrechtspraak hebben voorbehouden. ${ }^{79}$

Jottrand stelt dat de grondwetgever zich heeft beroepen op artikel 18 van hoofdstuk 5 onder Titel III van de Franse monarchale grondwet van 3 september 1791. Dit artikel stelt letterlijk dat:

'Niemand kan worden veroordeeld hetzij langs de burgerlijke, hetzij langs de strafrechtelijke weg, voor feiten gebaseerd op gedrukte of gepubliceerde werken, zonder als dusdanig schuldig te zijn

dienen des te meer gewicht te krijgen in het betoog. Schuermans kiest voor mercuriales uit de Julimonarchie, maar ook verwijzingen naar de perswetgeving van de Restauratiemonarchie komen aan bod, net als in de memorie van Jottrand. Zie R. Cahen, 'Joseph-Marie Portalis (1778-1858) et la liberté de la presse vers 1820', C@hiers du CRHIDI (2018), DOI10.25518/1370-2262.518.

${ }^{72}$ Brussel, 2 juni 1862, o.c., f ${ }^{\circ} 33$. BJ 1862, kol. 868-870.

${ }^{73}$ Jottrand, Mémoire. AN, s.n. Een ander exemplaar berust in de Koninklijke Bibliotheek van België, Afdeling Kostbare Werken, II 28.848 C 34/4.

${ }^{74}$ Ibid., 2.

${ }^{75}$ Ibid., 3. 'Un nom national par excellence; [...] non-seulement dans nos annales, mais encore dans nos légendes'.

${ }^{76}$ Huidig artikel 25. Velaers, De Grondwet, dl. I, 545. Delbecke, De lange schaduw, 49-98.

${ }^{77}$ Velaers, De Grondwet, dl. I, 559-560.

78 Jottrand, Mémoire, 10.

79 Over het 'politieke' gebruik van de juryrechtspraak, zie B. Delbecke en B. Debaenst (eds.), Malcontenten van de moderniteit. Het politiek misdrijf en de bescherming van de politieke structuren in België (1831-2015), Gent, Academia Press, 2015. 
erkend en verklaard door een jury. Indien $1^{\circ}$ er een misdrijf vervat zit in het betreffende geschrift en $2^{\circ}$ de vervolgde persoon schuldig is. ${ }^{, 80}$

Jottrand haalt ter ondersteuning van zijn these aan dat Joseph Lebeau (1794-1865) in de zitting van het Nationaal Congres op 28 december 1830 unaniem de stelling had laten aannemen dat 'in elk proces voor persmisdrijven de schuldigverklaring aan de jury behoort'. ${ }^{81}$ Uit de stelling van François de Sécus (1760-1836) op 22 januari 1831, in de eindfase van de bespreking van de Grondwet, leidt Jottrand dan weer af dat het ruime begrip van 1791 dient te primeren: 'De jury dient te worden hersteld in haar oorspronkelijke zuiverheid. Deze instelling is onder Bonaparte vervalst (faussée). ${ }^{82}$ Jottrand stelt dat de artikelen 14, 18 en 98 van de Grondwet de uitdrukking vormden van eenzelfde opinie. Toch staat de zin van Lebeau enkel in artikel 98, en niet in artikel 14 of $18 .{ }^{83}$ Jottrand vindt dat een aandachtige lezer de samenhang tussen de bepalingen zeker moet opmerken. De ongestructureerde behandeling van de artikelen door het Nationaal Congres, en ook de bespreking van verworpen amendementen, leiden volgens hem tot de conclusie dat de burgerlijke aansprakelijkheid niet werd uitgesloten, maar dat het oordeel erover werd voorbehouden aan de jury. ${ }^{84}$ De wetgever hoeft slechts een 'loi complémentaire' over persmisdrijven aan te nemen, en een procedure uit te werken om de private en publieke schade die eruit voortvloeit, te herstellen. ${ }^{85}$

Constitutionalist Jan Velaers stelt in zijn analyse van het voormalige artikel $18 \mathrm{Gw}$. dat het Nationaal Congres de vrijheid van meningsuiting absoluut wou maken om preventieve censuur te vermijden. Het achteraf aansprakelijk stellen van een burger op basis van de wet was géén beperking van deze vrijheid, maar een uiting van het principe 'vrijheid in verantwoordelijkheid'. ${ }^{86}$ Jottrand voerde daarentegen aan dat deze 'verantwoordelijkheid' enkel door een jury kon worden vastgesteld, ook voor schade aan particulieren. Dit is het punt waarop hij artikel 14 oud Gw. (het huidige artikel 19) ${ }^{87}$ aanhaalde. Dit artikel garandeerde zowel de vrijheid van meningsuiting als de vrijheid van eredienst. Enkel de 'repressie van delicten begaan bij het gebruik van deze vrijheden' vormde de grens voor de waarborg die de Grondwetgever wenste te verstrekken aan eenieder. Voor Jottrand week de Grondwet hiermee af van het algemeen natuurrechtelijk schadevergoedingsbeginsel uit artikel $1382 \mathrm{BW}$. Waarom ook niet, indien ook andere bepalingen in de Grondwet het particuliere belang ondergeschikte maakten aan het algemene? Enkel de burgerrechtelijke fouten die door een strafbepaling werden gesanctioneerd, konden op die manier nog aanleiding geven tot schadevergoeding. De grondwetgever had dit wellicht als een ongemak kunnen zien. Waarom zou de gewone wetgever, 'investi de toute l'autorité nécessaire pour réprimer les abus’, gewoon niet optreden om kennelijk excessieve misbruiken te voorkomen? ${ }^{88}$

Jottrand stelde dat de wetgever eenvoudig, met twee kleine wijzigingen, de ongewenste effecten van de 'ware intentie' van het Nationaal Congres kon temperen. Hij stelde in de eerste plaats voor om

80 Jottrand, Mémoire, 27. 'Nul ne peut être jugé, soit par la voie civile, soit par la voie criminelle, pour fait d'écrits imprimés ou publiés, sans qu'il ait été reconnu et déclaré par un juré : $1^{\circ} S^{\prime} i l$ y a délit dans l'écrit dénoncé ; $2^{\circ} \mathrm{Si}$ la personne poursuivie en est coupable'. Geraadpleegd op https://www.conseilconstitutionnel.fr/les-constitutions-dans-l-histoire/constitution-de-1791 22 april 2020. Over de oorsprong van deze instelling in de Belgische Grondwet, zie B. Delbecke, 'The Political Offence and the Safeguarding of the Nation State: Constitutional Ideals, French Legal Standards and Belgian Legal Practice, 1830-70', Comparative Legal History, 2013, 45-74.

${ }^{81}$ Ibid., 10. De liberaal en latere minister $(1831,1832-1834)$ en kabinetsleider (1840-1841) Joseph Lebeau uit Hoei was tijdens de zittingen van het Nationaal Congres tevens advocaat-generaal bij het hof van beroep te Luik.

82 Jottrand, Mémoire, 26.

${ }^{83}$ De zin werd overgebracht naar artikel $150 \mathrm{Gw}$ (het oude artikel 98). Velaers, De Grondwet, dl. I, 548.

${ }^{84}$ Jottrand, Mémoire, 25.

85 Ibid., 10.

${ }^{86}$ Velaers, De Grondwet, dl. I, 549.

87 ibid., dl. I, 325.

88 Jottrand, Mémoire, 11. Het citaat is van katholiek politicus Barthélémy-Théodore de Theux de Meylandt (1794-1874) uit Hasselt. Ibid., 23. 
een bepaling op te nemen zoals in de Franse wet van 17 mei 1819 over de repressie van persmisdrijven (die een bredere strafbaarstelling voorzag dan de Code Pénal van 1810). Vervolgens zou het volstaan ('un petit bout de loi') $)^{89}$ om in de Voorafgaande Titel van het Wetboek van Strafvordering een toegang tot de jury te openen voor particulieren, zodat ze niet afhankelijk zouden blijven van het Openbaar Ministerie om hun schade vergoed te zien. ${ }^{90}$

Particulieren zouden dus zelf het hof van assisen moeten kunnen benaderen. ${ }^{91}$ De burgerlijke rechtbank zou voor Jottrand enkel mogen worden gevat indien het hof al uitspraak had gedaan over de strafvordering. ${ }^{92}$ Deze in zijn ogen essentiële aanvullingen op artikel 14 had de wetgever niet ingevoerd. Maar kon men dan a contrario concluderen dat zijn interpretatie verkeerd was? Jottrand hield voet bij stuk en stelde dat het Nationaal Congres zich had laten inspireren door de 'monarchale' (sic) Grondwet van 1791, 'pur produit des idées de 89 [...] de la conscience humaine réveillée' ${ }^{93}$

Hij citeerde vervolgens uit een arrest van het Brusselse hof van beroep van 10 april 1862, waarbij het hof het Franse regime uit 1791 citeerde, maar met het voorbehoud dat de Code Pénal van 1791 voorzag in de strafbaarstelling van alle gevallen van beschuldiging of insinuatie die rechten van derden zouden kunnen schaden. Bovendien gaf dit systeem de mogelijkheid aan particulieren om anderen te vervolgen voor de jury, geïnspireerd op het Romeins recht, 'la mère commune de toutes les législations de notre continent européen' ${ }^{94}$ Helaas, verzuchtte Jottrand, is het systeem vervolgens verzwakt, verduisterd en uitgedoofd in de verschillende grondwetten en wetten die volgden. Maar waarom had de Grondwetgever niet gewoon kunnen willen terugkeren naar 1791?

Interne analyse van de besprekingen in het Nationaal Congres

Jottrand probeert een nieuwe afweging tot stand te brengen tussen de 'formele bescherming' van het recht op vrije meningsuiting (art. $14 \mathrm{Gw}$.) en 'andermans recht' op schadevergoeding als grens van dit eerste recht (art. $1382 \mathrm{BW}$ ). Waarom zou er een absoluut verbod moeten zijn om andermans recht te raken, als het particulier belang (van de schadelijder) hoe dan ook moet afgewogen worden tegen het algemeen belang?95 Zou een expliciete uitsluiting een sterker argument zijn dan 'une déclaration implicite résultant de la conséquence nécessaire à tirer d'un texte qui [...] n'a pu dire autre chose que ce qu'il fait entendre implicitement' $?^{96}$

Artikel 1382 BW had een onveranderd juridisch bestaan gekend met de Grondwet van het jaar VIII en alle opeenvolgende grondwetten tot en met die van het Verenigd Koninkrijk der Nederlanden (1815). In 1831 had het Nationaal Congres nochtans de zinsnede 'gegarandeerd, behoudens de repressie van de misdrijven begaan bij het uitoefenen van deze vrijheden' ingevoegd. Dit kon toch niet zonder betekenis zijn geweest? Jottrand verwijst verder naar het slotartikel van de Grondwet (het toenmalige

${ }^{89}$ Ibid., 19-20.

90 Ibid., 12.

${ }^{91}$ Jottrand maakt het onderscheid met het niet-aangenomen voorstel-Fleussu uit 1847, dat door toenmalig minister van Justitie d'Anethan werd gezien als strijdig met het algemeen principe van schadevergoedingsplicht uit artikel 1382 BW. De liberaal Joseph de Fleussu (1803-1858) uit Borgworm zou de burgerlijke vordering naar aanleiding van uitlatingen in de pers ondergeschikt hebben willen maken aan de openbare vordering. In Jottrands interpretatie is dit niet nodig, aangezien hij de toegang tot de jury wil opengooien voor particulieren. Ibid., 21.

92 Ibid., 19.

${ }^{93}$ Ibid., 13-14. Jottrand distantieert zich hier zowel van de Charte octroyée van 1814, die veel kenmerken van de Grondwet van het Verenigd Koninkrijk der Nederlanden bevatte, als van de 'idées de 93', die geassocieerd worden met de niet-ingevoerde Grondwet van het jaar I en de terechtstelling van Lodewijk XVI: 'en 1830, lorsqu'on avait effacé tous les intermédiaires des exagérations de 93, des réactions du directoire et de l'empire, et des restaurations ou quasi-restaurations de 1815' (Ibid., 27).

${ }^{94}$ Ibid., 13.
${ }^{95}$ Ibid., 15.
${ }^{96}$ Ibid., 15. 
artikel 139), dat oproept tot bijkomende wetgeving inzake de persvrijheid en de juryrechtspraak. Blijkt hier niet uit dat het Nationaal Congres de vigerende reikwijdte van artikel $1382 \mathrm{BW}$ wou wijzigen? ${ }^{97}$

Het initiële ontwerp van Grondwet voorzag dat de vrijheid van eredienst door de wet kon worden beperkt, in de gevallen waarbij orde en openbare rust werden bedreigd. Dit was uiteraard niet naar de zin van de katholieken. Volgens Jottrand diende de finale formulering, voorgesteld door de jurist Van Meenen (1772-1858), ${ }^{98}$ zo te worden gelezen dat ook particuliere eisen tot schadevergoeding voor de burgerlijke rechtbank, voortvloeiend uit de beoefening van de eredienst, onmogelijk werden gemaakt door de Grondwet:

'Ainsi, la circulation momentanément obstruée dans une rue par le passage d'une procession catholique et ayant empêché, par exemple, un Israélite d'arriver à temps à la bourse pour y conclure un marché urgent; ainsi la cloche d'un couvent ou celle d'une église sonnée trop fréquemment et trop bruyamment dans le voisinage d'un philosophe qu'elle troublerait ainsi dans ses méditations panthéistes ou autres; ainsi, les sorties véhémentes d'un sermon de missionnaire anabaptiste ou méthodiste, en pays catholique, contre les mours trop payennes [sic] des populations [...] n'aurait donné lieu à aucune réparation. ${ }^{99}$

Indien de tekst van Van Meenen niet was aanvaard, aldus Jottrand, zouden alle religies ten prooi zijn gevallen aan ontelbare burgerlijke vorderingen. Wie kon verdragen dat de bescherming van de vrijheid van meningsuiting geringer zou zijn dan die van de vrijheid van godsdienst? Enkel de (straf)wet mocht beperkingen aan deze vrijheden stellen. 'Delict' gelijkstellen met 'quasi-delict', zou de vrijheid van meningsuiting te zeer inperken en dus een ontradend effect hebben op de publieke opinie en de pers, precies wat de grondwetgever wou vermijden.

Verder voert Jottrand aan dat het voorstel van de liberaal Jean-Baptiste Nothomb om expliciet de burgerlijke aansprakelijkheid te vermelden bij de persvrijheid (art. 18), niét werd weerhouden. ${ }^{100}$ Niets bleef over van het voorstel om als beperking 'behoudens aansprakelijkheid voor publieke geschriften die de rechten van ofwel een individu, ofwel de samenleving, kwetsen' in te voegen. ${ }^{101}$ In de omgekeerde (te restrictieve zin) herinnerde Jottrand dan weer goedkeurend dat het Nationaal Congres de suggestie van de Robaulx (1798-1861) verworpen had om geen enkele wettelijke beperking toe te laten op het recht om 'het publieke leven en de daden van de autoriteiten te onderzoeken en te bekritiseren.' 102

\section{Inspiratie voor de grondwetgever}

Ten slotte staat Jottrand lang stil bij de verdediging van de jury in de Assemblée Nationale Constituante door Adrien Duport (1759-1798) en Jacques Guillaume Thouret (1746-1794) in 1790. ${ }^{103}$ Deze laatste zou met name ook de burgerlijke aansprakelijkheid hebben ondergebracht bij de garantie die de jury moest bieden aan de persvrijheid. ${ }^{104}$ Indien de Belgische grondwetgever 'imbu des idées de 89' was

${ }^{97}$ Ibid., 16. Jottrand leidt uit het stilzwijgen van het decreet van het Nationaal Congres van 19 juli 1831 af, dat men de burgerlijke aansprakelijkheid via de jury niet geregeld had, maar geenszins dat de wetgever dit had willen uitsluiten. Ibid., 20. Over het jurydecreet, zie Delbecke, De lange schaduw, 82-88; H. Schuermans, Code de la presse ou commentaire du décret du 20 juillet 1831 et des lois complétives de ce décret (Bruxelles 1861).

${ }^{98}$ Jottrand, Mémoire, 23.

${ }^{99}$ Ibid., 17.

100 Ibid., 24

${ }^{101}$ Ibid., 25

102 Ibid., 24. De Luikse radicaal de Robaulx stelde dat de pers in zich een tegengif droeg: de gekrenkte partij kon zich altijd revancheren via een publicatie in het orgaan dat een lasterlijke aantijging had geformuleerd. Witte, Belgische Republikeinen, 62, 271.

${ }^{103}$ De lectuur van deze bron is niet uitzonderlijk. Jean-Baptiste Nothomb, lid van het Nationaal Congres, gebruikte de handelingen van de Assemblée Nationale Constituante als lectuur in zijn studententijd. Delbecke, De lange schaduw, 36.

${ }^{104}$ Jottrand, Mémoire, 32. 
geweest, dan wist hij evenwel ook nog verder te kijken. Leefde de jury immers niet nog vrijer in het Britse en Amerikaanse recht? De uitbreiding van de jurygarantie in deze staten had geleid tot de 'consolidatie van de nationale instellingen', de ontwikkeling van welvaart en beschaving. Jottrand haalde de grondwet van de staat New York uit 1847 aan (die het heeft over 'incrimination' of 'indictments for libels'), en wat hij over de Engelse wetgeving inzake 'civil injuries' ('le libelle privé') kon terugvinden in de rechtsverzameling The Cabinet Lawyer. De jury zou in alle gevallen oordelen over 'feit en recht'. ${ }^{105}$

\section{De omvang van de schadevergoeding}

In ondergeschikte orde ${ }^{106}$ stelt Jottrand dat alleen de louter materiële schade in aanmerking mag worden genomen door het hof. Hij verwijst hiervoor naar Brusselse en Gentse rechtspraak sinds 1856. Het proces van de Spaanse generaal Ortega tegen de liberale Indépendance Belge, van de Ottomaanse diplomaat Vely Pacha tegen de krant Le Nord en van het Gentse college van burgemeester en schepenen tegen de Nouvelliste de Gand waren alle besloten zonder toekenning van vergoeding. ${ }^{107}$ Ortega had hetzelfde bedrag geëist als Rogier, maar de Brusselse rechtbank van eerste aanleg vond dat een tiende daarvan volstond, conform de kosten van de gerechtelijke vaststelling van de belediging. Een analoge beslissing werd getroffen in de zaak-Vely Pacha. Substituut-procureur des Konings de le Court had bij zijn advies al aangegeven dat het geëiste bedrag van tienduizend frank diende te worden verminderd. De publicist Louis Hymans had van de Indépendance Belge niet meer dan driehonderd frank toegewezen gekregen.

\section{Uitspraak in Beroep}

Het hof van beroep nam merkelijk meer tijd om de argumenten van Jottrand te weerleggen. De interpretatie van de wil van de grondwetgever van de appellant strekte ertoe om een radicale verandering te weeg te brengen inzake de bevoegdheid van de burgerlijke rechtbanken om kennis te nemen van deze vorderingen. Ondanks de ontwikkelde argumenten in zijn conclusies, kon Jottrand geen wettekst voorleggen die expliciet de voorheen geldende bevoegdheidsregels had afgeschaft. ${ }^{108}$ Dit is uiteraard de grote zwakte van het betoog van Jottrand, die -net als eerder magistraat Henri Schuermans in de kolommen van de Belgique Judiciaire- aangeeft dat het aan de wetgever toekomt 'de reprendre l'oeuvre de 1831, animé de la même sollicitude pour la presse que celle qui animait les auteurs de la Constitution'. Door zelf aan te geven dat een tussenkomst van de wetgever vereist is, geeft men de tegenstrever een uitstekend tegenargument. ${ }^{109}$

Hij wil -aldus het hof- een buitensporig privilege in het leven roepen, zonder dat er een formele regel voorhanden is om dit te staven. ${ }^{110}$ 'Losse meningen' ('Des opinions isolées') bij de bespreking van de Grondwet zijn onvoldoende om werkelijk geschade partijen de toegang tot de burgerlijke rechter te ontzeggen. Indien de grondwetgever het noodzakelijk had geacht om dit te doen, had er een precieze en formele bepaling voorhanden moeten zijn. ${ }^{11}$ Wie kan veronderstellen dat het Belgische 'corps constituant' een dergelijke belangrijke hervorming in het vage had willen laten?

Het hof houdt vast aan het idee dat de 'disposition tutélaire' van artikel 1382 van het Burgerlijk Wetboek op geen enkele manier kan zijn afgeschaft door artikel 14 van de Grondwet. Kon de grondwetgever hebben gewild om 'la licence, l'impunité la plus scandaleuse' in te stellen voor

105 Ibid., 33.

${ }^{106} \mathrm{Na}$ behandeling van het hoger aangehaalde argument over de begroting van de schadevergoeding onder de wet van 25 maart 1841. Ibid., 33-35.

${ }^{107}$ Ibid., 35.

${ }^{108}$ Afschrift Brussel 2 juni 1862, f. 48r ${ }^{\circ}$.

${ }^{109}$ H. Schuermans, 'De la liberté de la presse', kol. 433.

${ }^{110}$ Afschrift Brussel 2 juni 1862, f. 48r ${ }^{\circ}$.

${ }^{111}$ Ibid., f. 49r ${ }^{\circ}$. 
beledigingen? ${ }^{112}$ Het vormt geen beletsel dat de burgerlijke aansprakelijkheid (voor quasi-delicten) niet vermeld wordt als beperking op het recht van eenieder om zijn mening te uiten. ${ }^{113}$ Artikel 18 vormt evenmin een basis om te stellen dat de Grondwet de burgerlijke aansprakelijkheid zou beperken. Artikel 98 kan verwijzen naar wat letterlijk in de artikelen 14 en 18 is vermeld: de vervolging door de openbare macht. ${ }^{114}$

Jottrands pleidooi voor een minieme procedurele wijziging om ook voor de burgerlijke vordering de toegang tot het hof van Assisen mogelijk te maken, vindt evenmin genade. Het hof stelt dat het jurydecreet van 18 juli 1831 de bepalingen uit de Code d'Instruction Criminelle van 1808 inzake de jury herstelt, en dat expliciet vermelde afwijkingen enkel gelden voor de strafvordering. Het is naar geldend Belgisch recht mogelijk om de burgerlijke vordering autonoom in te stellen. Hoewel Jottrand de bevoegdheid van de burgerlijke rechtbanken betwist, voert hij overigens niet aan dat het aan de geïntimeerde verweten feit een misdrijf zou zijn.

Ten gronde stelt het arrest dat de Journal de Bruxelles de zaak alleen maar erger gemaakt heeft door tijdens de procedure commentaar te publiceren op de debatten voor de rechtbank van eerste aanleg. ${ }^{115}$ Het krantenartikel bekladt Rogier overduidelijk. De schadelijke intenties van de redactie worden nog duidelijker ( 'surabondamment manifestées') door de gemaakte verwijten. Kunnen we hierin een verwijzing zien naar de Journal de Bruxelles van 17 december, dat de rechtbanken afschildert als aanhangsels van de heersende politieke formatie? Volgens het hof was het toegekende bedrag dus geenszins buitensporig. ${ }^{116}$

\section{Cassatie}

Lucien Jottrand bracht de zaak van Delièvre voor het Hof van Cassatie, het toenmalige hoogste rechtscollege van het land. De bezwaren uit zijn uitgebreide conclusie werden ook gedeeld door meerdere stemmen uit de rechtsleer. ${ }^{117}$ Cassatie koos evenwel een totaal andere optie, door te poneren dat de grondwet een 'loi politique' was, die vreemd was aan de belangen van particulieren, die gevrijwaard zouden blijven door het burgerlijk recht als 'droit commun'. ${ }^{118}$

Het hof baseerde deze redenering op de napoleontische wetgeving, die voorafging aan de invoering van de Grondwet. ${ }^{119}$ Procureur-generaal Charles Faider $(1811-1893)^{120}$ herinnerde aan het natuurrechtelijk karakter van de verbintenis tot schadeherstel, die een zelfstandig bestaan kende, voorafgaand aan elke vorm van positief recht, met inbegrip van de Grondwet. ${ }^{121}$ De burgerlijke vordering was vrij, zelfs indien het schadeverwekkend feit gekwalificeerd kon worden als een misdrijf.

112 Ibid., f. 49r ${ }^{\circ}$.

113 Ibid., f. $49 \mathrm{v}^{\circ}$.

${ }^{114}$ Ibid., f. $51 \mathrm{v}^{\circ}$.

115 Ibid., f. $53 \mathrm{r}^{\circ}$.

116 'Histoire d'un journal', gepubliceerd door Le Petit Belge (1899), AN, inv. nr. 421 (krantenknipsels). Het gebrek aan scherpzinnigheid en koelbloedigheid bij Paul Nève wordt onderlijnd. In tegenstelling tot zijn voorgangers, wist hij het onderscheid niet te maken tussen energieke aanvallen op ideeën en op personen. AN, inv. nr. 421.

${ }^{117}$ Delbecke verwijst naar meerdere bijdragen in de Belgique Judiciaire in 1846, 1847 en 1861.

118 Cass. 24 januari 1863, Pas. 1864, I, 110-117, BJ 1863, kol. 261-262. La Meuse, 26 januari 1863; L'Echo du Parlement, 27 januari 1863; Le Bien Public, 24 en 26 januari 1863.

${ }^{119}$ Art. 7 Wet van 27 ventôse jaar VIII. Zie Loi sur l'organisation des tribunaux n' 1100: 'Les tribunaux de première instance connaîtront en premier et dernier ressort [...] des matières civiles.' Collection générale des lois, proclamations, arrétés [sic] et autres actes des pouvoirs législatif et exécutif, Paris, Imprimerie du dépôt des lois, an VIII de la République, t. V, 293.

${ }^{120}$ B. Delbecke, 'Gerechtelijke nationale cultuur en haar blinde vlek: de mercuriales en gelegenheidsredes van Charles Faider als procureur-generaal bij het Hof van Cassatie (1871-1885)', TRG, 75, 2007, 363-394.

${ }^{121}$ Cass. 24 januari 1863, Pas. 1864, I, 115-116. 
Voor Faider kon het 'efemere' en 'exorbitante' systeem van 1791, waarop Jottrand zijn 'sofisme' baseerde, niet worden gerechtvaardigd. ${ }^{122}$ Hij illustreerde dit met een paar schokkende voorbeelden:

'Ainsi, j'imprimerai que votre mère est une prostituée sortie de la fange; $j$ 'imprimerai que votre frère porte sur l'épaule la marque du faussaire; j'imprimerai que votre père est fils d'un bourreau; je serai à l'abri de toute poursuite même civile, car il n'y a pas délit punissable d'après nos lois!' 123

Waarom zouden overigens lasterlijke uitlatingen op café wél strafbaar zijn, maar de facto niet als ze gedrukt zouden worden op papier? De interpretatie van Jottrand was 'absurd, verkeerd, gevaarlijk' en 'asociaal'. ${ }^{124}$ Faider besloot zijn interventie door te stellen dat de Grondwet wel degelijk een bescherming voorzag voor de pers bij een burgerlijke vordering: het onpartijdige oordeel van de onafhankelijke magistratuur. ${ }^{125}$ Het Hof trad voor het overige de motivering van het hof van beroep bij.

Deze stelling was eerder gepubliceerd in een lokaal overzicht van rechtspraak gepatroneerd door de Luikse magistraten Jean Cloës (1796-1876) en Remacle Bonjean (1807-1887). ${ }^{126}$ De vlammende reactie in de Belgique Judiciaire sidderde van verontwaardiging. Hoe hadden beide magistraten in de kolommen van hun tijdschrift een dergelijk 'anti-juridique' en 'anti-constitutionnel' schrijfsel durven aanvaarden? ${ }^{127}$ De vrije keuze van de gekrenkte partij voor de buitencontractuele vordering was een 'ketterij' ${ }^{128}$ en een schending van zowel de geest als de tekst van de Grondwet van 1831. ${ }^{129}$

\section{Uitvoering}

De Journal de Bruxelles is ondanks de bij voorraad uitvoerbare rechterlijke uitspraken ten gronde, niet verdwenen, en bleef voortdurend verschenen. Hoe valt dit te verklaren? La Meuse schrijft op 2 juli 1862 dat Charles Rogiers welwillendheid de enige reden is waarom de krant nog kon bestaan. ${ }^{130}$ In de pleidooien van Orts in eerste aanleg kwam dit argument al naar voren: Rogier beweerde ook op de terechtzitting trouw te zijn gebleven aan zijn 'antécédents bien connus', en met name aan zijn vurige pleidooi voor de persvrijheid in 1847 , waarbij hij zich verzette tegen... de uitholling van de jury als waarborg in perszaken ${ }^{131}$ :

'Ces deux grandes garanties, pour lesquelles on peut dire que la révolution belge a été faite en partie, ces deux grandes garanties qui figuraient en tête du programme de l'Union qui a mis fin à la domination du régime hollandais, on semble aujourd'hui disposé à en faire bon marché. ${ }^{132}$

Rogier stelt in 1847 -tempora mutantur, et nos mutamur in illis- nog dat de bevoegdheid van de burgerlijke rechtbanken voor persdelicten (te lezen als delicten én quasi-delicten)... strijdig zou zijn met de Grondwet:

\footnotetext{
122 Ibid., 115.

123 Ibid.

124 Ibid.

125 Ibid., 116.
}

126 Delbecke, De lange schaduw, 435. De reactie van de redactie van La Belgique Judiciaire schrijft geen rechtstreeks auteurschap toe aan beide magistraten, maar heeft het over hun verantwoordelijkheid als hoofdredacteurs. Z., 'Liberté de la presse. De la responsabilité civile de l'éditeur, de l'imprimeur et du distributeur', BJ 1856, kol. 1009.

${ }^{127}$ Ibid., kol. 1015. Een 'interprétation judaïque de l'art. 18' (Ibid., kol. 1014).

${ }^{128}$ Ibid., kol. 1010.

${ }^{129}$ Ibid., kol. 1015.

${ }^{130}$ La Meuse, 2 juli 1862.

${ }^{131}$ Indépendance Belge, 22 december 1861; Delbecke, De lange schaduw, 436.

${ }^{132}$ Hand. Kamer, 23 maart 1847, 1279. 
'Je m'étonne alors que la Constitution déclare que tous les délits de la presse seront du ressort du jury, ces délits cependant peuvent être, même en matière publique, attribués aux tribunaux civils, du moment que les plaignants les saisissent d'une demande de dommages-intérêts. ${ }^{133}$

In hetzelfde artikel legt de redactie van La Meuse uit dat een gerechtsdeurwaarder zich heeft aangediend in de Kreupelenstraat nummer 13 te Brussel om er beslag te leggen op de drukinstallaties van Le Journal de Bruxelles. De eigenaar van de krant, Paul Nève, is evenwel tussengekomen om de aan hem toebehorende goederen op te eisen. Op maandag 1 juli 1862 verschenen alle partijen voor de rechtbank van eerste aanleg, voorgezeten door Vauthier, die eerder al twee maal ten gronde over de zaak had geoordeeld. Nève verscheen zonder raadsman, met enkel zijn pleitbezorger. Vauthier was niet overtuigd door de overgelegde bewijsstukken, en liet het executoriaal beslag verder gaan. De mildheid, rechtschapenheid en goedheid van Rogier zouden blijken uit zijn vraag om ook na deze mislukte poging van de tegenpartij, de krant toch gebruik te laten maken van het noodzakelijke materiaal om te drukken en te verschijnen.

Een maand later volgt evenwel een anticlimax. La Meuse bericht dat Paul Nève alsnog zijn slag heeft thuisgehaald. Rogier kan de toegekende tienduizend frank wellicht nooit nog bekomen. Delièvre heeft België verlaten, en Nève kan aantonen dat alle waardevolle roerende goederen ofwel eigendom zijn van de krant, ofwel door bestemming zijn verenigd met het huis, waarop een hypotheek rust bij de Banque Liégeoise. ${ }^{134}$ De kopie van de kwaliteiten voor de expeditie van de beslissing van de Brusselse rechtbank van eerste aanleg in privéarchief van de familie Nève geven de gebruikte argumenten weer. ${ }^{135}$ Josse Delièvre huurde alleen een kamer in het huis, en had geen enkele zakenrechtelijke band met het grootste deel van de inboedel die voor Rogier werd aangeslagen.

Paul Nève verzet zich inderdaad met succes tegen de inbeslagname van balen papier en drukinstallaties, door te verwijzen naar de verkoopovereenkomst die hij met kamerlid Coomans (18131896), destijds eigenaar en uitgever van L'Emancipation, had afgesloten in 1859 om de overdracht van de Journal de Bruxelles te regelen. ${ }^{136}$ Verder dienen de inventaris in de brandverzekeringspolis en een reeks facturen als een bijkomende aanwijzing van bezit te goeder trouw. De mechanische stoompers en de warmteketels van de stoommachines werden vergund door de Bestendige Deputatie van de Provincie Brabant in 1860. De Banque Liégeoise had bij notariële akte aan Nève een hypothecaire kredietopening toegestaan van honderdduizend frank, drie maanden voor de fatale zinnen in de krant verschenen.

De bittere commentaar van de redactie laat weinig aan duidelijkheid over:

'Cette affaire démontre une fois de plus la vérité de ce proverbe que pour les honnêtes gens c'est la justice qui est la loi, tandis que pour les habiles c'est la loi qui est la justice. ${ }^{137}$

${ }^{133}$ Ibid.

${ }^{134}$ La Meuse, 16 en 17 augustus 1862.

${ }^{135}$ Kwaliteiten voor de expeditie van het oordeel gegeven op 14 augustus 1862 door de eerste kamer van de rechtbank van eerste aanleg te Brussel, 23 augustus 1862 (kopie), Familie-AN, inv. nr. 115, 4 f.

${ }^{136}$ Dagvaardingsexploot van deurwaarder Verhasselt, 10 juli 1862, Familie-AN, inv. nr. 115. G. Braive, 'Les groupes de presse belges en 1858', Revue belge de Philologie et d'Histoire, 1967, 421: bisschop van Brugge Jean-Baptiste Malou (1809-1864) vroeg in 1858 samen met zijn broer, de vooraanstaande katholieke politicus Jules Malou (1810-1886), dat Paul Nève de Emancipation zou opkopen. De gematigde Coomans zou zich hiertegen verzet hebben, maar het dreigement van de Malous om de abonnees aan te raden hun steun aan de krant op te zeggen, deed hem van mening veranderen. In januari 1959 had Nève 'toute la presse conservatrice de la capitale' in handen. Het verdwijnen van L'Emancipation werd in de kolommen van La Meuse betreurd als het heengaan van de 'laatste gematigde katholieke krant'. Voor de cessie van de Emancipation en de Journal de Bruxelles kan men terecht bij het afschrift van de akte van oprichting van de Société de la presse conservatrice belge in het AN, inv. nummer 37; zie ook 'Histoire d'un journal', gepubliceerd door Le Petit Belge, 1899, AN, inv. nr. 421 (krantenknipsels).

${ }^{137}$ La Meuse, 16 en 17 augustus 1862. 


\section{Epiloog}

Het verhaal lijkt hiermee ten einde, tot La Meuse op 7 februari 1863 bericht dat Josse Delièvre in Brussel is opgedoken. Hij wordt meteen opgesloten in de gevangenis van de Kleine Karmelieten, en laat Paul Nève dagvaarden voor de burgerlijke rechtbank. Delièvre zou twintigduizend frank schadevergoeding eisen, en Nève als eigenaar van de krant in vrijwaring oproepen tegen alle mogelijke verdere eisen van Charles Rogier. Delièvre ontkent verder als drukker te zijn opgetreden: 'il est si peu l'imprimeur du Journal de Bruxelles qu'il n'est même pas imprimeur de son état. ${ }^{138}$ Paul Nève lijkt dus een perfide stromanconstructie te hebben opgezet. ${ }^{139}$ Een week later bericht La Meuse dat Nève zelf tienduizend frank heeft betaald aan Rogier: 'Il s'est exécuté'. De grootmoedige minister van Buitenlandse Zaken zou zich, onveranderlijk tronend op de Parnassus van het politieke liberalisme, bereid hebben verklaard om de som te storten in de onderlinge bijstandskas van de typografen. ${ }^{140}$

De positie van Paul Nève als sterke man van de Journal de Bruxelles wankelt. Kamerleden priester Désiré de Haerne (1804-1890, lid van het Nationaal Congres), Alphonse Nothomb (1817-1898) en Alexander Rodenbach (1786-1869) maken zich zorgen over de radicale weg die de Journal de Bruxelles is ingeslagen. De eenheid van de katholieke beweging zou in gevaar zijn. ${ }^{141}$ De krant laat zich meeslepen in polemieken over buitenlandse politiek, en bericht te weinig over de Belgische actualiteit. ${ }^{142}$ Nève zou ook in de overtuiging verkeerd hebben dat de talrijke liberale kranten in Brussel enkel bestreden konden worden door een unieke spreekbuis voor de hele katholieke wereld. Wie zijn krant concurrentie aandeed of bekritiseerde, werd zonder genade verketterd, ook al ging het om hooggeplaatste figuren als de latere aartsbisschop Victor Deschamps (1810-1883). ${ }^{143}$ In september 1863 blijkt de krant door Nève te zijn verkocht aan Alphonse Nothomb, Adolphe Dechamps (1807-1875) en anderen.

Paul Nève verdwijnt uit de kolommen van de krant. ${ }^{144}$ Hij is bij de Kamerverkiezingen van 1864 kandidaat in het arrondissement Ath, 'na de zeven mooiste jaren van zijn leven te hebben geofferd voor de verdediging van de conservatieve zaak'. ${ }^{145}$ Tijdens de onvermijdelijke polemieken in de kiesstrijd eist Nève een recht van antwoord in de liberale Indépendance Belge. Hij wenst met name te reageren op een bewering als zou hij 'amende honorable' gedaan hebben voor de beledigingen aan het adres van Rogier in de Journal de Bruxelles. Nève erkent de fout uit december 1861, maar schrijft haar (nog steeds) op het conto van de misleidende liberale pers, met name van de orangistische Messager de Gand. De redactie van de Indépendance Belge concludeert dat dit wel wat laat is. Pas nu hij in de kiescampagne schade kan oplopen door de herinnering aan het voorval, komt er een excuus. Had Nève dit niet beter in de rechtbank gedaan, waar hij enkel verschenen is om de verkoop van zijn huis af te wenden, maar nooit

${ }^{138}$ La Meuse, 7 februari 1863; L'Echo du Parlement, 7 februari 1863.

${ }^{139}$ Vrijgezel Nève haalt in de kiescampagne van 1864 aan dat Orts hem ervan zou beschuldigd hebben om in overspel te leven met de echtgenote van Delièvre, een dame van respectabele leeftijd, moeder van vijf kinderen. Orts insinueerde dus dat Delièvres verdwijnen op meer dan één manier in Nève's kaart speelde. Nève repliceerde met de beschuldiging dat Orts zich in een slecht gereputeerde protestantse kapel ophield met de echtgenote van een confrater. Paul Nève legde aan de gegoede plattelandskiezers in Ath uit dat men ook niet veel anders kon verwachten in Brussel, 'foyer de corruption et de perversité'. Journal d'Ath, 10 augustus 1864. AN, inv. nr. 379.

${ }^{140}$ La Meuse, 14 februari 1863.

${ }^{141}$ La Meuse, 19 februari 1863. De krantenknipsels uit Le Petit Belge (1899) schrijven de overname toe aan de chaotische financiën en de neiging van de immer opgewekte Paul Nève 'de dépenser sans compter [...] On marchait vers la faillite [...] M. Nève [...] riait de sa propre détresse. Ses créanciers, eux, ne riaient pas du tout'. De krant verloor abonnementen, waardoor bekwame medewerkers niet konden worden aangeworven. AN, inv. nr. 412.

142 Vander Vorst-Zeegers, Le “Journal de Bruxelles", 16-18.

${ }^{143}$ Histoire d'un journal, gepubliceerd door Le Petit Belge (1899), AN, inv. nr. 421.

${ }^{144}$ Ook al stelt La Meuse dat de Journal de Bruxelles in handen van de nieuwe vennootschap Société Nouvelle 'les haines de M. Paul Nève' geërfd zou hebben.

${ }^{145}$ Le Journal d'Ath, 10 augustus 1864. AN, inv. nr. 379. 
ten gronde? Wellicht, aldus de liberale krant, had Nève beter gebruik gemaakt van zijn vergane periode als 'maître absolu' van de Journal de Bruxelles. ${ }^{146}$

\section{Conclusie}

De grote schadevergoeding waartoe Delièvre veroordeeld wordt, doet de wenkbrauwen fronsen. Gezien de vooraanstaande politieke positie van Charles Rogier als medeleider van het kabinet en de verhitte context van het debat had deze vergoeding lager kunnen liggen. Het behoeft dan ook weinig verbazing dat Lucien Jottrand in zijn verdediging van drukker Delièvre heil zoekt in de juryrechtspraak. In zijn Constitution belge annotée neemt Thonissen een citaat op van de Geneefse publicist Sismondi (17731842):

'L'institution du jury [...] enlève au prince l'arme redoutable du pouvoir judiciaire, et le met dans l'impossibilité de gouverner et de se faire craindre par la menace des tribunaux; elle a désarmé le juge lui-même de tout ce qu'il pouvait avoir de redoutable. ${ }^{147}$

De argumentatie van Jottrand was gesteund op het stilzwijgen van het Nationaal Congres over de burgerlijke vordering bij persmisdrijven. ${ }^{148}$ Een vergelijking met de eerdere grondige analyse van Bram Delbecke over deze kwestie ${ }^{149}$ maakt duidelijk dat het hof van beroep en het Hof van Cassatie in de zaak-Rogier meer deden dan het toepassen van een evidente vaststaande rechtspraak. ${ }^{150}$ De arresten leggen het debat in de rechtsleer naast zich neer. Toch is de polemiek niet afgelopen: debat in de kolommen van de Belgique Judiciaire, wetsvoorstellen in het parlement en klachten uit journalistieke kringen tonen aan dat de discussie tot Wereldoorlog I wel degelijk leefde. Het gebruik van de burgerlijke vordering als wapen van private censuur werd blijvend gewantrouwd.

De schrik voor 'des peines ou amendes privées contre les journalistes '151 is logisch als men de feiten in de zaak tegen de Journal de Bruxelles in het achterhoofd houdt. De omvang van de schadevergoeding die Charles Rogier eiste, dreigde de belangrijkste oppositiekrant uit te schakelen. Op die manier kon langs burgerlijke weg het publieke debat aan banden worden gelegd. Dit argument is van een andere aard en gradatie dan de argumentatie van de Brusselse rechtbank van eerste aanleg, het Brusselse hof van beroep of het Hof van Cassatie, die allen verwijzen naar de straffeloosheid indien herstel via de aquiliaanse aansprakelijkheid ontzegd zou worden.

Ondanks de succesvolle argumentatie van zijn raadslieden, lijkt Charles Rogier zich uiteindelijk ook te hebben geconformeerd aan de geest van de Grondwet, door de krant zelf buiten schot te laten. Op die manier vinden we misschien toch nog een echo van de verontwaardiging in de Belgique Judiciaire van 10 augustus 1861 terug. Indien de geest van de Grondwet het niet onmogelijk maakt om

146 Indépendance Belge, 8 augustus 1864 (met recht van antwoord Paul Nève). Nève volhardt in de Journal d'Ath van 10 augustus 1864 dan weer in de boosheid: een nieuw stuk zou zijn gevonden in Kamerijk, waaruit zou blijken dat Rogier de lof zou gezongen hebben van Joseph Le Bon (1765-1795), priester-lid van de Convention Nationale en uitvoerder van de repressiepolitiek van het Comité de Salut Public.

147 Thonissen, La Constitution belge annotée, 293.

${ }^{148} \mathrm{Z}$., 'Liberté de la presse. De la responsabilité civile de l'éditeur, de l'imprimeur et du distributeur', $B J$ 1856, kol. 1010: 'Les constituants n'ont parlé [...] que de crime et de répression pénale; ils ne se sont pas occupés de la faute, encore moins du quasi-délit.'.

${ }^{149}$ Delbecke, De lange schaduw, 430-442.

${ }^{150}$ Zie bijvoorbeeld de beslissing van het Brusselse hof van beroep van 8 juli 1839 in de zaak van de Brusselse hotelhouder Deruyscher tegen Parys en Borgia, uitgever en auteur van een artikel in de satirische krant Méphistophélès. Het hof van beroep laat de burgerlijke vordering toe, maar past de getrapte verantwoordelijkheid toe, om zo de drukker buiten schot te laten en de krant verder te laten verschijnen, om 'private drukkerscensuur' te vermijden. Ibidem, 433.

${ }^{151}$ Georges Duplat, hoofdredacteur van Het Nieuws van den Dag, op het Belgische perscongres te Oostende, 29 juni-1 juli 1912, Ibidem, 442, noot 2261. 
een burgerlijke vordering tot schadevergoeding in te stellen, dan dient de toegekende schadevergoeding geen repressief karakter te hebben :

'Une constitution n'est pas plus une loi politique qu'une loi civile; elle est l'une et l'autre à la fois, ou plutôt elle est plus que l'une et plus que l'autre. Elle présente l'ensemble écrit des principes en vertu desquels un peuple entend se gouverner [...]. Elle marque au cachet de ses idées, elle pénètre son esprit, et par conséquent elle change, elle modifie toutes les lois, lois civiles, lois pénales, lois de procédure, lois d'instruction criminelle. ${ }^{152}$

${ }^{152}$ Z., 'Liberté de la presse', $B J$ 1856, kol. 1010. 